\title{
康复训练活动分析法对老年脑卒中 偏痽患者下肢运动功能的影响
}

\author{
吕 梦*, 王海洲, 郡珠平 \\ 徐州市中心医院北院,江苏徐州 221000 \\ *通信作者:吕梦,E-mail:dzhxga@163.com \\ 收稿日期: 2020-01-05; 接受日期 : 2020-02-27 \\ 基金项目: 江苏省徐州市科技计划项目 (KC18190) \\ DOI : $10.3724 /$ SP.J.1329.2020.02012
}

开放科学 (资源服务) 标识码 (OSID):

摘要 目的: 观察康复训绕活动分析法对于老年脑卒中后偏㿈患者步行能力及运动功能的影响。方法: 选取 老年脑卒中后偏痽患者 104 例, 按照随机数字表法分为对照组和观察组, 每组 52 例。对照组实施关节平衡稳 定训练、重心转移训练、肌力强化训练、步行训练、上下楼梯训练等常规康复治疗, 观察组在对照组基础上实 施下肢康复训练活动分析法。选择香港职业治疗协会的日常生活活动能力分析评估量表中与下肢运动相关 的活动项目进行训练, 训练过程中定期对每个训练项目进行评分, 若评分 $\leqslant 1$ 分, 则将训练环境由活动室逐 渐向真实环境过渡, 然后进行针对性强化训练, 主要色括: 限制健手使用、强化患侧上肢训练等, 每日训练 $6 \mathrm{~h}$, 每周 $5 \mathrm{~d}$, 连续干预 3 个月。比较 2 组的活动分析法评分、Holden 步行功能评分、步行 $10 \mathrm{~m}$ 所需时间、FuglMeyer 运动功能(FMA)评分。结果: 与治疗前比较, 2 组治疗 1、2、3 个月后的活动分析法评分、Holden 步行能 力评分、运动功能评分均明显升高, 步行 $10 \mathrm{~m}$ 时间明显降低, 差异有统计学意义 $(P<0.05)$; 与对照组比较, 观察组活动分析法评分、Holden 步行能力评分、运动功能评分均更高, 步行 $10 \mathrm{~m}$ 时间更短。结论: 应用康复 训练活动分析法治疗老年脑卒中后偏痽患者, 可有效改善患者步行能力、运动功能, 提高患者下肢肢体活动 能力, 值得临床推广。

关键词 脑卒中;偏㿈;下肢康复训练;活动分析法;步行能力;运动功能

脑卒中是中老年人常见病、多发病,是由于脑 部血管突然破裂或血管阻塞所致脑血流减少而引 起脑组织损伤的一组疾病, 具有发病率高、死亡率 高、致残率高等特点 ${ }^{[1]}$ 。偏㿈是脑卒中最常见的后遗 症之一, 患者常一侧肢体肌力减退、活动不利或完 全不能活动 ${ }^{[2]}$, 有研究指出约 $80 \%$ 脑卒中患者下肢 运动功能受到损害, 这严重影响了患者的日常活动 范围, 降低生活质量 ${ }^{[3]}$ 。改善步行能力是脑卒中后偏 㿈患者康复治疗最主要的目的之一, 恢复下肢运动 功能是脑卒中患者的第一诉求 ${ }^{[4]}$ 。近年来, 下肢康复 训练是临床上应用较为普遍的康复训练方法 ${ }^{[5]}$, 但 其康复效果不尽如人意, 还需要进一步改善 ${ }^{[6]}$ 。活动
分析法是通过与日常生活密切相关的康复训练, 帮助 脑卒中患者逐步恢复正常生活, 临床评价较好 ${ }^{[7]}$ 。本. 研究基于下肢康复训练活动分析法干预老年脑卒 中偏㿈患者,取得较好临床疗效,现报告如下。

\section{1 临床资料}

\section{1 病例选择标准}

1.1.1 诊断标准 根据全国第四届脑血管病学术 会议制订的脑卒中诊断标准 ${ }^{[8]}$ 。

1.1.2 纳人标准 (1) 符合上述诊断标准, 并经头颖 CT 或 MRI 确诊; (2) 患者首次发病, 病程 $<5$ 个月; (3) 年龄: 60 90 岁; (4) 生命体征平稳, 意识清楚;

引用格式: 吕梦,王海洲, 邵珠平. 康复训练活动分析法对老年脑卒中偏痽患者下肢运动功能的影响 [J]. 康复学报, 2020,30(2): 145-148,161.

LV M, WANG H Z, SHAO Z P. Rehabilitation training activity analysis method for motor function in lower limb in elderly patients with hemiplegia after stroke [J]. Rehabilitation Medicine, 2020,30(2):145-148,161

DOI: $10.3724 /$ SP.J.1329.2020.02012 
(5) 伴有下肢功能障碍, 偏㿈侧下肢 Brunnstrom 分 期 $\leqslant$ III 期; (6) 患侧关节无外伤、疼痛、手术史等影响 训练的因素; (7) 患者及家属自愿签署知情同意书。

1.1.3 排除标准 (1) 伴有严重心、肺、肝、肾等脏器 疾病; (2) 合并恶性肿瘤; (3) 既往有精神病史或痴呆 病史; (4) 充血性心力衰竭; (5) 四肢痽㾂; (6) 听力障 碍、交流困难,无法配合训练。

1.1.4 脱落和中止标准 (1) 受试者依从性差, 无法 严格执行治疗防范; (2) 试验过程中, 病情突然加重
或死亡; (3) 受试者中途转院或其他原因退出。

\section{2 一般资料}

选取 2016 年 2 月一 2018 年 2 月在徐州市中心 医院北院治疗的老年脑卒中后偏痽住院患者 104 例, 采用随机数字表法分为对照组和观察组, 每组 52 例。2 组性别、年龄、病程、疾病类型、患侧、 Brunnstrom 分期等一般资料比较, 差异无统计学意 义 $(P>0.05)$, 具有可比性。见表 1 。本研究方案经徐 州市中心医院北院伦理委员会审批通过。

表 12 组一般资料比较 $(\bar{x} \pm s)$

Table 1 Comparison of general data between two groups $(\bar{x} \pm s)$

\begin{tabular}{|c|c|c|c|c|c|c|c|c|c|c|c|}
\hline \multirow{2}{*}{ 组 别 } & \multirow{2}{*}{$n$} & \multicolumn{2}{|c|}{ 性别 } & \multirow{2}{*}{ 年龄/岁 } & \multirow{2}{*}{ 病程/周 } & \multicolumn{2}{|c|}{ 疾病类型 } & \multicolumn{2}{|c|}{ 患侧 } & \multicolumn{2}{|c|}{ Brunnstrom 分期 } \\
\hline & & 男 & 女 & & & 脑出血 & 脑梗死 & 左侧 & 右侧 & II 级 & III 级 \\
\hline 对照组 & 52 & 33 & 19 & $71.34 \pm 6.47$ & $10.54 \pm 6.93$ & 23 & 29 & 27 & 25 & 29 & 23 \\
\hline 观察组 & 52 & 31 & 21 & $71.64 \pm 5.64$ & $10.75 \pm 6.67$ & 24 & 28 & 26 & 26 & 27 & 25 \\
\hline
\end{tabular}

\section{2 方 法}

\section{1 治疗方法}

2.1.1 对照组 实施常规康复训练。训练前告知患 者训练的意义、目的及具体方案, 以获得其良好配 合。训练项目包括关节平衡稳定训练、重心转移训 练、肌力强化训练、步行训练、上下楼梯训练等。具 体操作如下: (1) 侧卧位 (健侧在下) 做髋关节屈、伸 运动, $40 \mathrm{~s} /$ 组, 20 组/次, 3 次 $/ \mathrm{d}$ 。(2)仰卧位做髀关 节外旋、内旋、内收、外展运动, $40 \mathrm{~s} /$ 组, 20 组/次, 3 次 $/ \mathrm{d} 。(3$ 摆放仰卧位, 将双小腿悬垂于床面以下, 拍 打髂腰肌, 做屈骹、屈膝运动, $1 \mathrm{~min} /$ 组, 20 组/次, 3 次 $/ \mathrm{d}$ 。(4) 摆放俯卧位, 拍打智大肌, 再做伸髋运

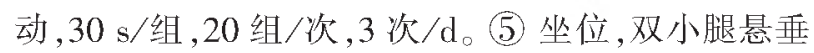
向下, 左右缓慢摆动患侧小腿, 做髂关节外旋、内旋 运动, $30 \mathrm{~s} /$ 组, 20 组/次, 3 次 $/ \mathrm{d}$ 。(6) 足跟离墙 $20 \sim 25 \mathrm{~cm}$ 背靠站立, 以肩膀作为支点, 向前挺出骨 盆, 做伸髋动作, 维持 $4 \sim 6 \mathrm{~s}$, 再缓缓将腰部贴回墙 面, $1 \mathrm{~min} /$ 组, 10 组/次, 3 次/ $\mathrm{d}$ 。(7) 摆放患侧半㻊 位, 保持肩、髋、膝平衡, 并前、后、左、右移动重心, $2 \mathrm{~min} /$ 组, 8 组/次, 3 次/ $\mathrm{d}$ 。(8)下肢适当负重, 进行 患侧单腿站立及上下楼梯训练, $20 \mathrm{~min} /$ 次, 3 次/ $\mathrm{d}$ 。 按以上顺序每天轮流选择 3 个项目进行训练。

2.1.2 观察组 在对照组基础上实施下肢康复训 练活动分析法, 相应操作均由经过专业培训并通过 考核的责任护士进行。具体如下: 选择香港职业治 疗协会的日常生活活动能力分析评估量表 ${ }^{[9]}$ 中与下 肢运动相关的活动项目进行训练, 如坐位转移、床
椅转移、平地行走、弯腰捡物等, 将某一活动分为若 干个小动作, 如坐位转移分为站起-行走-坐下; 床 椅转移分为床上坐位-床边坐位-站起-行走-坐下 等。依次执行各动作, 并进行评分。若患者某项活动 评分 $\leqslant 1$ 分, 则将训练环境由活动室逐渐向真实环 境过渡, 然后进行针对性强化训练, 主要包括: (1) 限 制健手使用: 休息位手夹板限制健手使用, 并且 用吊带限制健侧上肢活动, 当睡觉、洗澡、上厕所等 可影响平衡或安全时解除强制, 每天保持 $90 \%$ 以上 清醒时间佩戴强制性装置, 连续干预 2 周; (2) 强化 患侧上肢训练: 训练动作主要为穿线钉、堆杯、垂直 套圈、打高尔夫球以及翻麻将牌等活动, 每日训练 $6 \mathrm{~h}$, 每周 $5 \mathrm{~d}$, 连续干预 3 个月。

\section{2 观察指标}

2.2.1 活动分析法评分 采用香港职业治疗协会 的日常生活活动能力分析评估表对患者进行评估, 主要包括功能活动、自理活动 2 部分。共 16 项内容, 功能活动包含床上活动、卧位转移、坐位转移、床椅 转移、平地行走、弯腰捡物 6 项; 自理活动包含梳 头、洗脸、进食、口腔卫生、穿上衣、穿裤子、穿鞋、如 则、如则清洁、洗澡准备、洗澡 10 项。每项 $0 \sim 4$ 分, 总分 $0 \sim 64$ 分, 得分越高表示患者活动能力越好。

2.2.2 步行能力评价 (1) 采用 Holden 步行功能分 级量表 ${ }^{[10]}$ 对患者步行能力进行评价。分为 $0 \sim 5$ 级, 采用 $0 \sim 5$ 分量化赋分。级别越高, 步行功能越好。 (2) 测试患者步行 $10 \mathrm{~m}$ 所需要的时间。

2.2.3 肢体运动功能评价采用 Fugl-Meyer 运动 功能评定 (Fugl-Meyer assessment, FMA) 量表进行 
运动功能评估 ${ }^{[11]}$ 。FMA 量表包括上肢、下肢 2 部分, 上肢积分 66 分,下肢积分 34 分, 总分 100 分, 得分 越高表示患者肢体功能越好。

2 组分别于治疗前、治疗 1 个月、 2 个月、 3 个月 后进行以上项目测评。

\section{3 统计学方法}

采用 SPSS 19.0 统计软件进行数据分析。计量 资料符合正态分布采用 $(\bar{x} \pm s)$ 表示, 组内治疗前后比
较采用重复测量方差分析, 组间比较采用两独立样 本 $t$ 检验; 计数资料采用 $\chi^{2}$ 检验。 $P<0.05$ 为差异有 统计学意义。

\section{3 结 果}

\subsection{2 组治疗前后活动分析法评分比较}

见表 2。

表 22 组治疗前后活动分析法评分比较 $(\bar{x} \pm s)$

Table 2 Comparison of activity analysis scores before and after treatment between two groups $(\bar{x} \pm s)$

\begin{tabular}{ccclll}
\hline 组别 & $n$ & 治疗前 & 治疗 1 个月后 & 治疗 2 个月后 & 治疗 3 个月后 \\
\hline 对照组 & 52 & $31.46 \pm 6.27$ & $36.83 \pm 5.38^{1)}$ & $41.38 \pm 6.74^{1)}$ & $45.72 \pm 4.68^{1)}$ \\
观察组 & 52 & $30.53 \pm 6.82$ & $45.26 \pm 5.17^{12)}$ & $51.47 \pm 6.29^{122}$ & $59.63 \pm 3.27^{122}$ \\
\hline
\end{tabular}

注: 与治疗前比较, 1) $P<0.05$; 与对照组比较, 2) $P<0.05$ 。

Note: Compared with before treatment, 1) $P<0.05$; Compared with the control group, 2) $P<0.05$.

\subsection{2 组治疗前后步行能力比较}

见表 3 。

表 32 组治疗前后步行能力比较 $(\bar{x} \pm s)$

Table 3 Comparison of walking ability before and after treatment between two groups $(\bar{x} \pm s)$

\begin{tabular}{|c|c|c|c|c|}
\hline 组 别 & $n$ & 时间 & Holden 评分 & 步行 $10 \mathrm{~m}$ 时间 $/ \mathrm{s}$ \\
\hline \multirow{4}{*}{ 对照组 } & \multirow{4}{*}{52} & 治疗前 & $1.03 \pm 0.11$ & $226.57 \pm 16.57$ \\
\hline & & 治疗 1 个月后 & $1.15 \pm 0.14^{1)}$ & $205.53 \pm 14.38^{12}$ \\
\hline & & 治疗 2 个月后 & $1.79 \pm 0.20^{1)}$ & $185.29 \pm 15.48^{1)}$ \\
\hline & & 治疗 3 个月后 & $2.58 \pm 0.21^{1)}$ & $173.47 \pm 16.64^{1)}$ \\
\hline \multirow{4}{*}{ 观察组 } & \multirow{4}{*}{52} & 治疗前 & $1.02 \pm 0.16$ & $228.64 \pm 17.38$ \\
\hline & & 治疗 1 个月后 & $2.26 \pm 0.13^{1 / 2)}$ & $165.63 \pm 16.47^{1 / 2)}$ \\
\hline & & 治疗 2 个月后 & $3.14 \pm 0.16^{1 / 2)}$ & $136.48 \pm 15.62^{1 / 2)}$ \\
\hline & & 治疗 3 个月后 & $4.26 \pm 0.26^{1 / 2)}$ & $114.64 \pm 14.52^{1 / 2)}$ \\
\hline
\end{tabular}

注: 与治疗前比较, 1) $P<0.05$; 与对照组同一时点比较, 2) $P<0.05$ 。

Note: Compared with before treatment, 1) $P<0.05$; Compared with the control group at the same time, 2) $P<0.05$.

3.32 组治疗前后运动功能比较

见表 4。

表 42 组治疗前后 FMA 评分比较 $(\bar{x} \pm s)$

Table 4 Comparison of FMA scores before and after treatment between two groups $(\bar{x} \pm s)$

\begin{tabular}{ccclll}
\hline 组别 & $n$ & 治疗前 & 治疗 1 个月后 & 治疗 2 个月后 & 治疗 3 个月后 \\
\hline 对照组 & 52 & $47.63 \pm 10.58$ & $53.59 \pm 8.52^{1)}$ & $62.49 \pm 8.62^{1)}$ & $71.48 \pm 9.74^{1)}$ \\
观察组 & 52 & $45.73 \pm 11.47$ & $62.61 \pm 9.74^{122}$ & $73.54 \pm 9.47^{122}$ & $86.17 \pm 8.52^{122)}$ \\
\hline
\end{tabular}

注: 与治疗前比较, 1) $P<0.05$; 与对照组比较, 2) $P<0.05$ 。

Note: Compared with before treatment, 1) $P<0.05$; Compared with the control group, 2) $P<0.05$.

\section{4 讨 论}

据统计全球现有约 2500 万脑卒中患者,其中 中国约有 700 万脑卒中患者,超过 $70 \%$ 的患者伴有 不同程度的功能障碍, 其中以肢体功能障碍的影响
最为突出。脑卒中患者肢体功能障碍特别是下肢功 能障碍给患者日常生活带来较大困扰, 极大延缓了 其重返社会的进程, 步态异常、重心转移差和各关 节活动受限是脑卒中患者肢体功能障碍康复的重 要因素。下肢功能康复训练是目前临床上应用较为 
广泛的康复疗法, 它能有效帮助脑卒中患者改善下 肢运动功能, 提高患者日常生活活动能力。但其大 多是针对下肢运动功能、平衡功能的训练, 涉及患 者日常生活密切相关动作训练的研究相对较少。本 研究采用下肢康复训练活动分析法对老年脑卒中 偏㿈患者进行治疗, 结果显示, 治疗 $1 、 2 、 3$ 个月后, 观察组活动分析法评分、Holden 步行能力评分、运 动功能评分均明显高于对照组; 观察组步行 $10 \mathrm{~m}$ 时间明显低于对照组。这提示, 康复训练活动分析 法应用于老年脑卒中后偏㿈患者治疗, 可有效改善 患者步行能力、运动功能, 提高患者下肢肢体活动 能力。

首先, 本研究根据日常生活活动能力分析评估 表中的 16 项活动, 依次练习其分解动作, 并由治疗 人员进行评分, 对评分 $\leqslant 1$ 分的活动项目加大训练 密集度,这些康复训练项目不仅针对骼、膝关节等 进行固定训练, 还注重加强与患者日常生活紧密相 关的动作训练 ${ }^{[12]}$, 这对改善患者肢体活动能力, 提 高日常生活活动能力具有重要意义。其次, 通过康 复训练活动分析法有针对性指导脑卒中偏痽患者 进行坐位转移、床椅转移、平地行走等日常生活动 作康复训练, 这里强调的是进行一系列连续动作的 康复训练 ${ }^{[13]}$, 而非单独地分解训练动作, 这样更有 利于帮助患者恢复下肢肢体的整体功能; 在康复训 练过程中, 定期对患者的训练效果进行评分, 根据 评分结果有针对性调整各个训练项目的强度和密 集度, 使评分较低的训练项目通过强化训练得到加 强 ${ }^{[14]}$, 从而提升脑卒中偏㿈患者下肢肢体的整体功 能, 这比对照组相对机械的康复训练效果更好一些。 最后, 强化脑卒中偏痽患者日常生活相关动作的康 复训练, 通过这种强化的运动模式输人不断刺激大 脑皮质, 有助于唤醒患者大脑及肌肉的记忆性, 从 而帮助建立正确的运动模式 ${ }^{[15]}$ 。

\section{5 小 结}

下肢康复训练活动分析法应用于老年脑卒中 后偏痽患者治疗可有效改善其肢体活动及步行能 力,提高运动功能,值得临床推广。

\section{参考文献}

[1] 姚爽. 偏痽治疗仪结合分级功能训练在脑梗死患者中的应用 与治疗 [J]. 天津护理, 2018,26(1):75-76.

[2] 刘智慧. 偏㿈肢体康复训练护理在脑梗死护理中的应用效 果 $[J]$. 实用临床护理学电子杂志, 2018,3(12):37.

[3] HOROWITZ J D, DE CATERINA R, HERESZTYN T, et al. Asymmetric and symmetric dimethylarginine predict outcomes in patients with atrial fibrillation:an ARISTOTLE substudy $[\mathrm{J}]$. J Am Coll Cardiol , 2018, 72(7): 721-733.

[4]林玲, 厉美云, 胡军言, 等. 康复训练结合运动想象在脑梗死 偏痽患者康复护理中的应用 $[\mathrm{J}]$. 中西医结合护理 (中英文), $2017,3(10): 39-41$.

[5]黄亦琳. 脑梗死偏㿈病人治疗干预措施研究进展 $[\mathrm{J}]$. 全科护 理, 2017,15(24):2970-2972.

[6] SAMANTA D. Unilateral cerebral atrophy : severe neuroimaging feature of incontinentiapigmenti without acute encephalopathic state $[J]$. J Pediatr Neurosci, 2018,13(2):270-272.

[7]王华, 符晓艳, 江礼, 等. 3 种不同护理干预方法在脑梗死偏 㿈患者中的应用效果 $[J]$. 中国临床治疗, 2017,9(4):286288.

[8]第四届全国脑血管病学术会议. 各类脑血管疾病诊断要点 $[\mathrm{J}]$. 中华神经科杂志, $1996,29(6): 379-380$.

[9] PANAGOPOULOS D, LOUKOPOULOU S, KARANASIOS E, et al. Cerebral hemorrhagic infarction as the initial manifestation of deep venous thrombosis in a child with patent foramen ovale $[\mathrm{J}]$. Glob Cardiol Sci Pract, 2018,2018(2): 17.

[10］赵丽华, 陈爱霞, 蔡张慧. 早期康复护理促进脑梗死偏痽患者 患肢功能恢复的 Meta 分析 $[\mathrm{J}]$. 实用临床护理学电子杂志, $2017,2(3): 76-77$.

[11] 利春玲, 陈晓君, 李华清, 等. 延续性护理对脑梗死偏㿈病 人运动功能和日常自理能力的影响 [J]. 全科护理, 2017, 15 (36): $4538-4540$.

[12] 林源, 王丽, 苏翠红, 等. 简易日常生活功能训练方案在急性 椇梗死偏㿈患者中的初步应用 $[\mathrm{J}]$. 解放军护理杂志, 2017, $34(6): 18-21,40$.

[13] MYAKOTNYKH V S, OSTAPCHUK E S, POSTOVALOVA V L. The main diseases and syndromes identified in patients of elderly and senile age, hospitalized in the hospitals of a different profile [J]. Adv Gerontol, 2018,31(2):250-259.

[14]陈捷, 吴福春, 莫国清, 等. 新 Bobath 技术结合智能运动反馈 训练对脑卒中偏㿈患者手功能的影响 $[\mathrm{J}]$. 康复学报, 2018, $28(6): 16-20$.

[15]秦茵, 黄冬娥, 康国辉, 等. 头穴重复经颎磁刺激治疗脑卒中 后上肢痉挛性偏㿈疗效观察 $[\mathrm{J}]$. 康复学报, 2018, 28(6):2125 .

(下转第 161 页) 


\title{
Meta Analysis of Clustering Nursing for Stroke Associated Pneumonia
}

\author{
HAN Chunyan ${ }^{1}$, ZHAO Cun ${ }^{1}$, WANG Xinglei ${ }^{2}$, CHANG Yali ${ }^{1}$, YAO Li ${ }^{1}, \mathrm{KE}_{\text {Yihong }}{ }^{1}$, TIAN Jinhui ${ }^{3}$, DOU Xinman ${ }^{1,2^{*}}$ \\ ${ }^{1}$ School of Nursing, Lanzhou University, Lanzhou, Gansu 730010, China; \\ ${ }^{2}$ The Second Hospital of Lanzhou University, Lanzhou, Gansu 730030, China; \\ ${ }^{3}$ The Evidence Based Medicine Center of Lanzhou University, Lanzhou, Gansu 730000, China \\ *Correspondence: DOU Xinman, E-mail: douxm@1zu.edu.cn
}

\begin{abstract}
Objective: To evaluate the impact of clustering nursing on stroke-related pneumonia by Meta-analysis, and provide a scientific basis for improving the prognosis of stroke patients. Methods: We searched in Wanfang database, CNKI, China Biomedical Literature database, PubMed, Web of Science, EMbase, and Cochrane Library database. The objects were patients with stroke. The trials (RCTs) included randomized controlled was about clustering nursing intervention for stroke-related pneumonia. The search period is from the construction of the database to January, 2018. The main outcome indicators were the incidence of stroke-related pneumonia, the incidence of aspiration, and the hospitalization, the secondary outcome indicators were hospitalization costs, mortality, and swallowing function. Two researchers independently screened the literature, extracted the data, and evaluated the quality of the included studies. The quality evaluation used the Cochrane Collaboration's bias risk assessment tool. The data was analyzed using RevMan 5.3 statistical software. The continuous variables used standardized mean difference (SMD) and 95\% CI as the effect indicators. The dichotomous variables used odds ratio $(O R)$ and $95 \% C I$ as the effect indicators. If the homogeneity between the studies was good $(P \geqslant$ $\left.0.1, I^{2} \leqslant 50 \%\right)$, select the fixed effect model, if there was heterogeneity between these studies $(P<0.1, I>50 \%)$, analyze the source of heterogeneity, and if there was no clinical heterogeneity, choose a random effects model. Results: A total of 11 clinical randomized controlled trial literatures were finally included. They were all in Chinese, with a total of 1048 patients. Meta analysis results showed that the incidence of SAP in the cluster care group was $[O R=0.31,95 \% C I(0.22,0.44), P<0.00001]$, and the incidence of aspiration was $[O R=0.19,95 \% C I(0.10,0.33), P<0.00001]$, hospitalization [lighter group: $S M D=-0.82,95 \% C I(-1.09,-0.54), P<0.00001$, severe group: $S M D=-5.38,95 \% C I(-6.02,-4.74), P<0.00001]$ were significantly lower than those of the conventional nursing group, and the differences were statistically significant $(P<0.05)$. Conclusion: Clustering nursing can prevent the occurrence of SAP, reduce the incidence of aspiration, shorten the hospitalization, and is worthy of clinical application. However, the literature data, the quality of the literature will have a greater impact on the research results. Therefore, in the next step, it is necessary to conduct more high-quality, large-sample research in strict accordance with the requirements of the experiment to provide reliable evidence for the implementation of clustering nursing evidence.
\end{abstract}

KEY WORDS stroke; associated pneumonia; clustering nursing; meta analysis

DOI: $10.3724 /$ SP.J.1329.2020.02014

(上接第 148 页)

\section{Rehabilitation Training Activity Analysis Method for Motor Function in Lower Limb in Elderly Patients with Hemiplegia after Stroke}

\author{
LYU Meng*, WANG Haizhou, SHAO Zhuping \\ North Hospital of Xuzhou Central Hospital, Xuzhou, Jiangsu 221000, China \\ *Correspondence: LV Meng, E-mail: dzhxga@163.com
}

\begin{abstract}
Objective: To observe the effect on rehabilitation training activity analysis for walking ability and motor function in elderly patients with hemiplegia after stroke. Methods: A total of 104 elderly patients with hemiplegia after stroke were randomly divided into control group and observation group, with 52 cases in each group. The control group received routine rehabilitation treatments such as joint balance stabilization training, center-of-gravity transfer training, muscle strengthening training, walking training, and up and down stairs training. The observation group received lower limb rehabilitation training activity analysis based on the control group. We selected some activities related to lower limb movements in the Hong Kong Occupational Therapy Association's daily life activity assessment scale for training. During the training process, we regularly gave a score for each training item. If the score of some training items was equal to or less than 1 , we should transform the training environment from activity room to real environment, and carry out intensive training on these items, such as restrict healthy hand to use, strengthen the affected upper limb training, etc. six hours per day, five days per week, continuous treatment for three months. The activity analysis scores, Holden walking function scores, time of walking for $10 \mathrm{~m}$, and Fugl-Meyer motor function scores were compared between two groups. Results: Compared with before treatment, the activity analysis score, Holden walking ability score, and motor function score of the both groups were significantly increased after 1,2 and 3 months after treatment, while the $10 \mathrm{~m}$ walking time was significantly reduced, and the differences were statistically significant $(P<0.05)$, Compared with the control group, the activity analysis score, Holden walking ability score, and motor function score of the observation group were higher, and the $10 \mathrm{~m}$ walking time was shorter. Conclusion: Rehabilitation training activity analysis method for treatment of elderly patients with hemiplegia after stroke can effectively improve the walking ability, motor function and lower limb physical activity ability of patients with hemiplegia after stroke.
\end{abstract}

KEY WORDS stroke; hemiplegia; lower limb rehabilitation training; activity analysis method; walking ability; motor function DOI: $10.3724 /$ SP.J.1329.2020.02012 